\title{
Soil-aquifer phenomena affecting groundwater under vertisols: a review
}

\author{
D. Kurtzman ${ }^{1}$, S. Baram ${ }^{2}$, and O. Dahan ${ }^{3}$ \\ ${ }^{1}$ Institute of Soil, Water and Environmental Sciences, The Volcani Center, Agricultural Research Organization, \\ P.O. Box 6, Bet Dagan 50250, Israel \\ ${ }^{2}$ Dept. of Land, Air and Water Resources, University of California Davis, CA 95616, USA \\ ${ }^{3}$ Dept. of Hydrology and Microbiology, Zuckerberg Institute for Water Research, Blaustein Institutes for \\ Desert Research, Ben Gurion University of the Negev, Sde Boker Campus, Negev 84990, Israel
}

Correspondence to: D. Kurtzman (daniel@volcani.agri.gov.il)

Received: 30 July 2015 - Published in Hydrol. Earth Syst. Sci. Discuss.: 21 September 2015

Revised: 13 December 2015 - Accepted: 15 December 2015 - Published: 15 January 2016

\begin{abstract}
Vertisols are cracking clayey soils that (i) usually form in alluvial lowlands where, normally, groundwater pools into aquifers; (ii) have different types of voids (due to cracking), which make flow and transport of water, solutes and gas complex; and (iii) are regarded as fertile soils in many areas. The combination of these characteristics results in the unique soil-aquifer phenomena that are highlighted and summarized in this review. The review is divided into the following four sections: (1) soil cracks as preferential pathways for water and contaminants: in this section lysimeter-to basin-scale observations that show the significance of cracks as preferential-flow paths in vertisols, which bypass matrix blocks in the unsaturated zone, are summarized. Relatively fresh-water recharge and groundwater contamination from these fluxes and their modeling are reviewed; (2) soil cracks as deep evaporators and unsaturated-zone salinity: deep sediment samples under uncultivated vertisols in semiarid regions reveal a dry (immobile), saline matrix, partly due to enhanced evaporation through soil cracks. Observations of this phenomenon are compiled in this section and the mechanism of evapoconcentration due to air flow in the cracks is discussed; (3) impact of cultivation on flushing of the unsaturated zone and aquifer salinization: the third section examines studies reporting that land-use change of vertisols from native land to cropland promotes greater fluxes through the saline unsaturated-zone matrix, eventually flushing salts to the aquifer. Different degrees of salt flushing are assessed as well as aquifer salinization on different scales, and a comparison is made with aquifers under other soils; (4) rela-
\end{abstract}

tively little nitrate contamination in aquifers under vertisols: in this section we turn the light on observations showing that aquifers under cultivated vertisols are somewhat resistant to groundwater contamination by nitrate (the major agriculturally related groundwater problem). Denitrification is probably the main mechanism supporting this resistance, whereas a certain degree of anion-exchange capacity may have a retarding effect as well.

\section{Introduction}

Vertisols can be briefly defined as soils with $30 \%$ or more clay to a depth of $50 \mathrm{~cm}$ that have shrinking/swelling properties (Brady and Weil, 2002). More detailed definitions require the existence of a subsurface vertic horizon in which slickenside features are formed by the shrink/swell dynamics (FAO Corporate Document Repository, 2015; IUSS Working Group WRB, 2014). Other names used for these types of soils are vertosols (common in Australian studies, e.g., Radford et al., 2009; Silburn et al., 2009; Gunawardena et al., 2011; Ringrose-Voase and Nadelko, 2013), and the more general cracking clays (e.g., Bronswijk, 1991; Liu et al., 2010). This latter generic term emphasizes both the hydrological complexity of these soils due to the inherent discontinuities (cracks) and their relevance for agriculture, being heavy, relatively fertile soils in many semiarid regions (good water-holding capacity, relatively higher organic content, etc.). Vertisols usually form in lowlands (Yaalon, 1997) 
where, typically, groundwater pools into alluvial aquifers. Hence, the interface between agricultural activity on these soils and the underlying groundwater resources is both complex and relevant. This review focuses on vertisol studies that have implications for the underlying groundwater resources; it does not cover the substantial body of literature concerning shrinking/swelling dynamics and its modeling (e.g., Bronswijk, 1988; Chertkov et al., 2004; te Brake et al., 2013), the purely agricultural and mineralogical aspects of vertisols (e.g., Bhattacharyya et al., 1993; Ahmad and Mermut, 1996; Hati et al., 2007) or environmental topics like the capacity of vertisols to sequester carbon (Hua et al., 2014).

Vertisols cover 335 million hectares out of a total earth land area of 14.8 billion hectares (2.3\%). The largest areas covered with vertisols are in eastern Australia, India, SudanEthiopia and Argentina-Uruguay (FAO Corporate Document Repository, 2015). Smaller areas of vertisols are found in various countries (e.g., China, Israel, Mexico, Spain, Tunisia, USA and many more). Although vertisols are very hard when dry, and very sticky when wet (making them difficult to till), in semiarid regions, irrigated crops such as cotton, corn, wheat, soybeans and others are grown on this soil. We acknowledge the dominant contribution of Australia to the literature on agro-hydrological aspects of vertisols. Conclusions from those studies have strengthened and generalized some of the findings obtained by the authors of this review in vertisol-groundwater studies in Israel, and have motivated this review (e.g., Arnon et al., 2008; Kurtzman and Scanlon, 2011; Baram et al., 2012a, b, 2013; Kurtzman et al., 2013).

The review is divided into four sections, which are partially connected and together deal with major issues concerning aquifers under agricultural land: recharge, salinization and nitrate contamination (other contaminants are mentioned as well). The following four sections cover the most general and relevant issues concerning soil-aquifers phenomena under vertisols:

- soil cracks as preferential pathways for water and contaminants (Sect. 2)

- soil cracks as deep evaporators and unsaturated-zone salinity (Sect. 3)

- impact of cultivation on flushing of the unsaturated zone and aquifer salinization (Sect. 4)

- the relatively little nitrate contamination in aquifers under vertisols (Sect. 5).

\section{Soil cracks as preferential pathways for water and contaminants}

There are probably hundreds of studies that acknowledge preferential flow and transport through cracks in clays - too many to be mentioned here. This section aims to review works from the soil-column and lysimeter scale to the basin and aquifer scales that show the relations between preferential flow via cracks, deep drainage, and aquifer recharge and contamination. It also provides a short description of the development of models of preferential flow and transport through soil cracks.

\subsection{Preferential flow of water in vertisols - evidence from the lysimeter to aquifer scale}

On a small scale, Kosmas et al. (1991) observed bypass flow through cracks in clayey soils from Greece using undisturbed soil columns (authors' terminology) with a diameter of $23 \mathrm{~cm}$. Ringrose-Voase and Nadelko (2013) measured flow in preferential paths directly using a field lysimeter that was installed $2 \mathrm{~m}$ below the surface of a furrow-irrigated cotton field without disturbing the overlying soil. Significant drainage was collected in this study when the hydraulic gradient in the matrix was in the upward direction, advocating drainage through preferential pathways that bypasses the matrix. In a paragraph on tension-lysimeters measurements, Silburn et al. (2013) acknowledge that "deep drainage measured at $1 \mathrm{~m}$ depth was dominated by matrix flow, with only $10 \%$ of drainage attributed to preferential flow (note that the soil was never dry enough to crack)", pointing out that under wellirrigated vertisols matrix deep-drainage and recharge may be of importance despite the low saturated hydraulic conductivity of the clay. A weighing-lysimeter experiment in irrigated vertisols in eastern Australia revealed a complex drainage mechanism following spray irrigation, where only deep parts of the cracks act as preferential pathways for the drainage when the top soil is moist and uncracked (Greve et al., 2010).

On the field scale $\left(\sim 100-1000 \mathrm{~m}^{2}\right)$, a similar phenomenon - i.e., open cracks at depth when surface cracks are mostly sealed - was reported by Baram et al. (2012b) throughout the rainy season in Israel. These authors compared transient deep (up to $12 \mathrm{~m}$ ) water-content data collected by vadose-zone-monitoring systems (VMSs; Dahan et al., 2009) at various sites, including very sandy soils; the comparison showed that by far, the fastest propagation of wetting fronts in deep vadose zones is observed in cracking clays.

Ben-Hur and Assouline (2002) conducted measurements of runoff in a vertisol cotton field in Israel that was irrigated with a moving sprinkler irrigation system. They observed that the high infiltration of runoff through soil cracks limited the overall surface runoff from the field. Other field-scale vadose-zone studies reported that preferential flow through cracked clay enhances infiltration from rice paddies (Liu et al., 2004). Losses of up to $83 \%$ of the water to deep drainage (including preferential and/or matrix flows) during furrow irrigation of cotton and sugar cane in vertisols were reported (Raine and Bakker, 1996; Dalton et al., 2001; Moss et al., 2001; Smith et al., 2005). Losses to deep drainage averaged $42.5 \mathrm{~mm}$ per irrigation (Smith et al., 2005), ranging from 50 to $300 \mathrm{~mm} \mathrm{yr}^{-1}$ (Silburn and Montgomery, 2004). Chen et 
al. (2002) and Bandyopadhyay et al. (2010) showed that the transition from flood to micro-sprinkler irrigation and careful scheduling of water-application rates can dramatically reduce water losses and contaminant transport due to deep drainage. Observation from groundwater supported this phenomenon: Acworth and Timms (2009) used nested piezometers and automated logging of groundwater levels and electrical conductivity to show evidence of shallow-aquifer $(16 \mathrm{~m}$ depth) freshening (decrease in salinity) due to fast deep drainage of irrigation water during the irrigation season.

At the small-watershed scale $\left(\sim 10000 \mathrm{~m}^{2}\right)$, Pathak et al. (2013) indicated that runoff from vertisols is smaller than runoff from sandier soils (alfisols) in an agricultural watershed near Hyderabad, India. The smaller runoff from the vertisols was attributed to preferential infiltration of local runoff into the soil cracks. Similar observations of minimal drainage and rapid recharge of shallow groundwater $(\sim 3 \mathrm{~m})$ below a vertisol-shale watershed in Texas following rainstorms were reported by Allen et al. (2005) and Arnold et al. (2005). This process was most dominant during the first rainstorms when the cracks were fully developed (at the end of the dry season).

On the aquifer scale $\left(100+\mathrm{km}^{2}\right)$, Kurtzman and Scanlon (2011) concluded that parts of the Israeli coastal aquifer overlaid by vertisols were fresh (before the influence of modern intensive cultivation) only due to recharge flow through preferential paths that bypassed the saline vadose-zone matrix. Dafny and Silburn (2014) reported that following the growing evidence of the feasibility of percolation through cracking clays, several recent studies have included a component of diffuse recharge in their assumptions or models of the Condamine River alluvial aquifer in Australia. This diffused recharge originates in deep drainage flowing through clay matrix and/or preferential paths.

\subsection{Preferential transport in vertisols}

In the last 2 decades, many transport studies with dyes and/or other conservative tracers (e.g., bromide, $\mathrm{Br}^{-}$) have indicated the pervasiveness of deep preferential transport through cracks in vertisols. Bronswijk et al. (1995) sprayed a bromide solution on cracking clays in the Netherlands that overlay a shallow water table $(\sim 1 \mathrm{~m}$ from ground surface). The authors reported rapid (on the order of days after rain event) preferential transport of $\mathrm{Br}^{-}$into the groundwater, and relatively fast (weeks to months) propagation within the vadose zone. Bronswijk et al. (1995) concluded that large cracks control the rapid transport of $\mathrm{Br}^{-}$to the groundwater, and preferential paths made up of tortuous mesopores control transport in the unsaturated zone (suggesting that transport through vertisols could be described as a triple domain medium-macropores, mesopores and matrix). Van Dam (2000) used the Crack module in SWAP to model the aforementioned experiment. This effort improved fits to the observations (relative to a single-domain model), but the variability of $\mathrm{Br}^{-}$in the unsaturated zone still could not be well reproduced. Lin and McInnes (1995) used dye to study and model flow in vertisols. They showed that infiltrating water passes first through the soil cracks and then into the soil matrix; they concluded that uniform flow through the soil cannot be used to describe the dye transport. A dye experiment in a soil column consisting of a sandy A horizon and a vertic clay B horizon showed preferential downward flow through the cracks in horizon B, bypassing more than $94 \%$ of the matrix (Hardie et al., 2011).

Kelly and Pomes (1998) estimated equivalent hydraulic conductivities from arrival times of $\mathrm{Br}^{-}$and ${ }^{15} \mathrm{~N}$-labeled nitrate in gravity lysimeters installed above and under a clay pan in Missouri (USA). They reported equivalent conductivities that were 4 orders of magnitude higher than the saturated hydraulic conductivity of the clay matrix.

Unlike tracers used in experiments, fast transport of herbicides and pesticides is of concern in aquifers and drainage systems down gradient from cultivated fields. Graham et al. (1992) reported that in cultivated vertisols in California (USA), herbicides were only found deep below the root zone in samples taken from the cracks' walls and not within the matrix, suggesting rapid transport of herbicides through the cracks, either as solutes or on colloids. Transport of pesticides in preferential-flow paths absorbed on colloids was also suggested for cotton fields on vertisols in Australia (Weaver et al., 2012). Early and deep drainage of herbicides from a lysimeter in cracking clays in the UK (early meaning well before reaching field capacity in the matrix) was reported by Harris et al. (1994). Similarly, fast arrival of herbicides to drains in cultivated clays was observed by Tediosi et al. (2013) on a larger scale (small catchment).

Due to the fact that in semiarid regions vertisols are arable, agriculture-oriented settlements have developed on these soils. In many cases, these settlements include concentrated animal feeding operations (CAFOs), such as dairy farms. Arnon et al. (2008) reported deep transport (> $40 \mathrm{~m}$ ) of estrogen and testosterone hormones into the unsaturated zone under an unlined dairy-waste lagoon constructed in a $6 \mathrm{~m}$ thick vertisol in Israel. They concluded that deep transport of such highly sorptive contaminants can only occur by preferential transport. Baram et al. (2012a, b) reported that preferential infiltration of dairy effluents through the cracks at the same site can transport water and solutes into the deep unsaturated zone. Locally, groundwater under dairy farm areas also shows relatively high concentrations of nitrate (Baram et al., 2014).

Figure 1 provides a visual summary of Sect. 2.1 and 2.2. It shows the potential for matrix-bypassing groundwater recharge and pollution under vertisols. Passing the biogeoactive matrix enables both freshwater recharge and transport of reactive substances. 


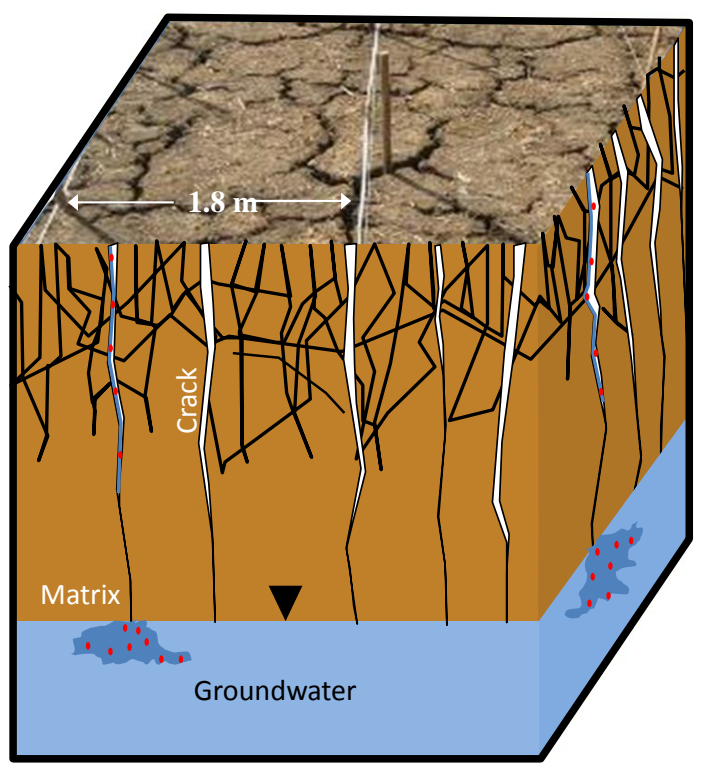

Figure 1. Illustration of potential fluxes of water and pollutants that bypass the matrix, which is typical of vertisols.

\subsection{Development of flow and transport models in cracking clays}

The field evidence described above motivated the development of quantitative methods to enable better predictions of flow and transport from ground surface to water table under vertisols. Nevertheless, modeling of unsaturated flow and transport as a dual (or multiple) domain in their different variants (e.g., mobile-immobile, dual porosity, dual permeability) did not develop exclusively to deal with cracking clays. Macropores such as voids between aggregates, or worm holes, are the preferential-flow paths of interest in many agricultural problems. Computer codes for modeling unsaturated preferential flow include among others: MACRO (Jarvis et al., 1994) and nonequilibrium flow and transport in HYDRUS (Šimůnek and van Genuchten, 2008). For further information on the kinematic wave approach used in MACRO, the reader is referred to German and Beven (1985); for comparative reviews of the different models and codes see Šimůnek et al. (2003), Gerke (2006), Köhne et al. (2009) and Beven and Germann (2013). The latter is critical of the common use of the Richards (1931) formulation in single and multiple-domain unsaturated-flow simulators.

One of the earlier crack-specific unsaturated-flow models was developed by Hoogmoed and Bouma (1980), who coupled vertical (crack) and horizontal (into the matrix) 1$\mathrm{D}$ models using morphological data for parameterization of the linkage between the two flows. Novák et al. (2000) attached a FRACTURE module to HYDRUS in which a source term was added to the Richards equation accounting for infiltration from the bottom of the fractures, bypassing matrix bulks. Van Dam (2000), added a crack sub-model to SWAP (van Dam et al., 2008) and Hendriks et al. (1999) used a code called FLOCR/AMINO, to study flow and transport phenomenon in shallow and cracked clayey unsaturated-zones in the Netherlands. A model of herbicide transport through the preferential paths was fitted successfully with the improved MACRO version 5.1 (Larsbo et al., 2005).

A more comprehensive dual-permeability module for 2-D and 3-D variably saturated models was introduced into HYDRUS much later (Šimůnek et al., 2012) following the formulations of Gerke and van Genuchten (1993). Coppola et al. (2012) took another step forward in modeling flow and transport in cracking clays by also introducing cracking dynamics (adopting formulation of Chertkov, 2005) into a dualpermeability flow and transport model.

\section{Soil cracks as deep evaporators and unsaturated-zone salinity}

Whereas during rain events or under irrigation, cracks are a concern in terms of loss of water and fertilizers and/or contamination of groundwater (Sect. 2), under dry conditions, deep soil cracks are relevant for their evaporation capacity from deep parts of the soil column. Kurtzman and Scanlon (2011), Baram et al. (2013) and others have reported the low water content and high salinity typical of the sediment matrix under uncultivated vertisols. Deep chloride profiles under native-land vertisols often show an increase in salinity down to 1-3 $\mathrm{m}$ and a relatively constant concentration in deeper parts of the vadose zone (e.g., Radford et al., 2009; Kurtzman and Scanlon, 2011; Silburn et al., 2011). In the reported cases from Israel, water uptake by roots was limited to the upper $1 \mathrm{~m}$ of the soil profile and to the rainy season, and therefore could not fully explain the increase in salinization in the deeper layers. Deep cracks form an additional mechanism of deep evaporation that supports the chloride profiles and low water content in the matrix under vertisols.

Sun and Cornish (2005) used SWAT to model runoff and groundwater recharge at the catchment scale $\left(\sim 500 \mathrm{~km}^{2}\right)$ in a vertisolic catchment in eastern Australia. Considering water balances at this scale, they concluded that recharge models need to have a component that enables taking moisture out of the lower soil profile or groundwater during dry periods. Trees with roots in groundwater and deep soil cracks can maintain deep evaporation in long dry periods. Another, indirect observation that supports evaporation through cracks in vertisol was reported by Liu et al. (2010). In this work discrepancies between satellite and model estimates of soil water content in dry seasons in vertisols are assumed to be related to the extra evaporation through the cracks. Both localand higher-scale observations and analyses point to a possible significant role of soil cracks as deep evaporators in dry periods.

Baram et al. (2013) suggested a conceptual model termed desiccation-crack-induced salinization (DCIS) based on pre- 


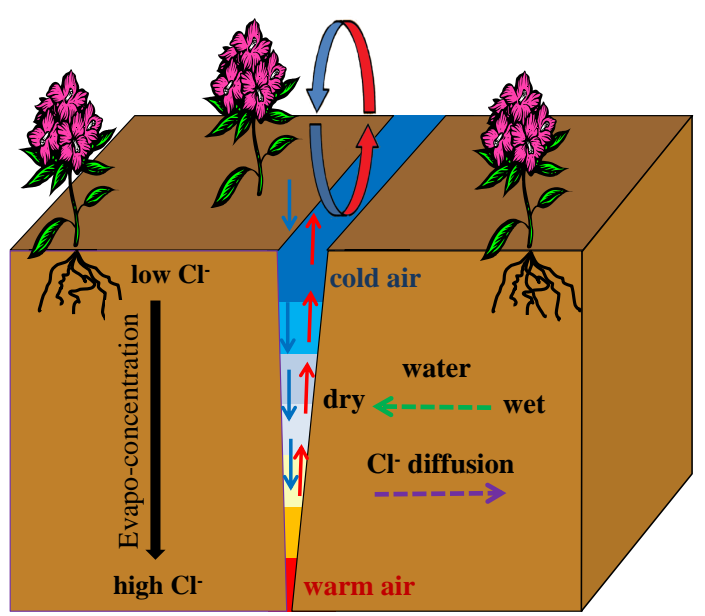

Figure 2. Desiccation-crack-induced salinization (DCIS), Baram et al. (2013). Convective instability of air in soil cracks, occurring mainly at night, leads to drying and salinization of the unsaturated zone.

vious work on subsurface evaporation and salinization in rock fractures (e.g., Weisbrod and Dragila, 2006; Nachshon et al., 2008; Kamai et al., 2009; Weisbrod et al., 2009). In DCIS, vertical convective flow of air in the cracks is driven by instability due to cold (and dense) air in the crack near the surface and warmer air down in deeper parts of the crack at night or other surface-cooling periods. The difference in the relative humidity between the invading surface air (low humidity) and the escaping air (high humidity) leads to subsurface evaporation and salt buildup (Fig. 2). Earlier studies that support the significance of evaporation via cracks in vertisols through field and laboratory observations include: Selim and Kirkham (1970), Chan and Hodgson (1981) and Adams and Hanks (1964). The latter showed enhanced evaporation from crack walls due to increase in surface wind velocity, this is another mechanism (in addition to surface cooling described before) causing instability in the crack's air, hence convection, evaporation and salt build up.

Leaching of salts from horizontal flow through the crack network evident in salinity rise in tail water of furrowirrigated fields in cracking clays in California was reported by Rhoades et al. (1997). This Californian study acknowledge that this phenomenon was not observed in similar fields (crop and irrigation technique) in lighter soils with no cracks.

In many semiarid regions, deep matrix percolation under non-cultivated vertisols is very small due to the clay's high retention capacity and low hydraulic conductivity, root uptake of the natural vegetation in the rainy season and further evaporation through cracks in dry periods. Low water content in the deeper unsaturated zone results in low hydraulic conductivities and makes aquifer recharge through matrix flow very small year-round. Matrix fluxes on the order of $1 \mathrm{~mm} \mathrm{yr}^{-1}$ under the root/crack zone were reported in a number of studies (e.g., Silburn et al., 2009; Kurtzman and Scan- lon, 2011; Timms et al., 2012). These very low water fluxes contain the conservative ions (e.g., chloride) originating from $200-600 \mathrm{~mm} \mathrm{yr}^{-1}$ of precipitation (with salts from wet and dry fallout) that enter the matrix at soil surface. Therefore, a dry (relatively immobile) and salty deep unsaturated matrix, developed for centuries-millennia under these non-cultivated vertisols. Nevertheless, some fresh recharge to the underlying aquifer through preferential paths related to cracks during heavy rain events creates an anomaly whereby relatively fresh water in the aquifer (e.g., $\sim 250 \mathrm{mg} \mathrm{L}^{-1}$ chloride; Kurtzman and Scanlon, 2011) lies beneath a salty and immobile unsaturated zone with porewater chloride concentration of a few thousands of milligrams per liter (O'Leary, 1996; Kurtzman and Scanlon, 2011; Tolmie et al., 2011; Baram et al., 2013). River, mountain-front, paleo- or other types of recharge may contribute, as well, to a situation where a relatively fresh aquifer exists under a saline vadose zone.

\section{Impact of cultivation on flushing of the unsaturated zone and aquifer salinization}

The anomalous situation of fresh groundwater under a saline unsaturated zone found in some native-land vertisols in semiarid regions exists due to the efficient evapotranspiration by natural vegetation and cracks (making deep unsaturated matrix immobile and saline) and fresh groundwater recharge through preferential flow in cracks or other types of recharge. However, what happens when natural conditions are changed to less favorable for native-vegetation and soil cracks (e.g., cultivated land and more ever irrigated intensive cropping)? The answer is obvious: higher fluxes may develop in the unsaturated matrix, which will flush salts and ultimately cause salinization of the underlying aquifer.

A large bulk of literature from eastern Australia has reported increased deep-drainage and leaching of salts, and in some cases, salinization of aquifers under cultivated vertisols. A typical increase in deep drainage from $<1 \mathrm{~mm} \mathrm{yr}^{-1}$ under native conditions to $10-20 \mathrm{~mm} \mathrm{yr}^{-1}$ under rain-fed cropping were reported by Silburn et al. (2009); Timms et al. (2012) and Young et al. (2014); whereas variable deep fluxes often in the 100 's $\mathrm{mm} \mathrm{yr}^{-1}$ range were reported for irrigated fields (mostly furrow-irrigated cotton; Gunwardena et al., 2011; Silburn et al., 2013; Weaver et al., 2013). These deep fluxes desolate salts that accumulated in the vadose zone in the native-vegetation period, moving them down towards the water table (Fig. 3). Earlier studies reporting leaching of salts from the vadose zone after clearing of natural eucalyptus trees for cropping include Allison and Hughes (1983) and Jolly et al. (1989), who worked in semiarid zones in southern Australia. In those studies, neither vertisols nor the role of soil cracks was mentioned; however, deep eucalyptus roots act similar to cracks to form a very saline and immobile deep-unsaturated-zone matrix, which becomes more mobile and less saline after the land- 

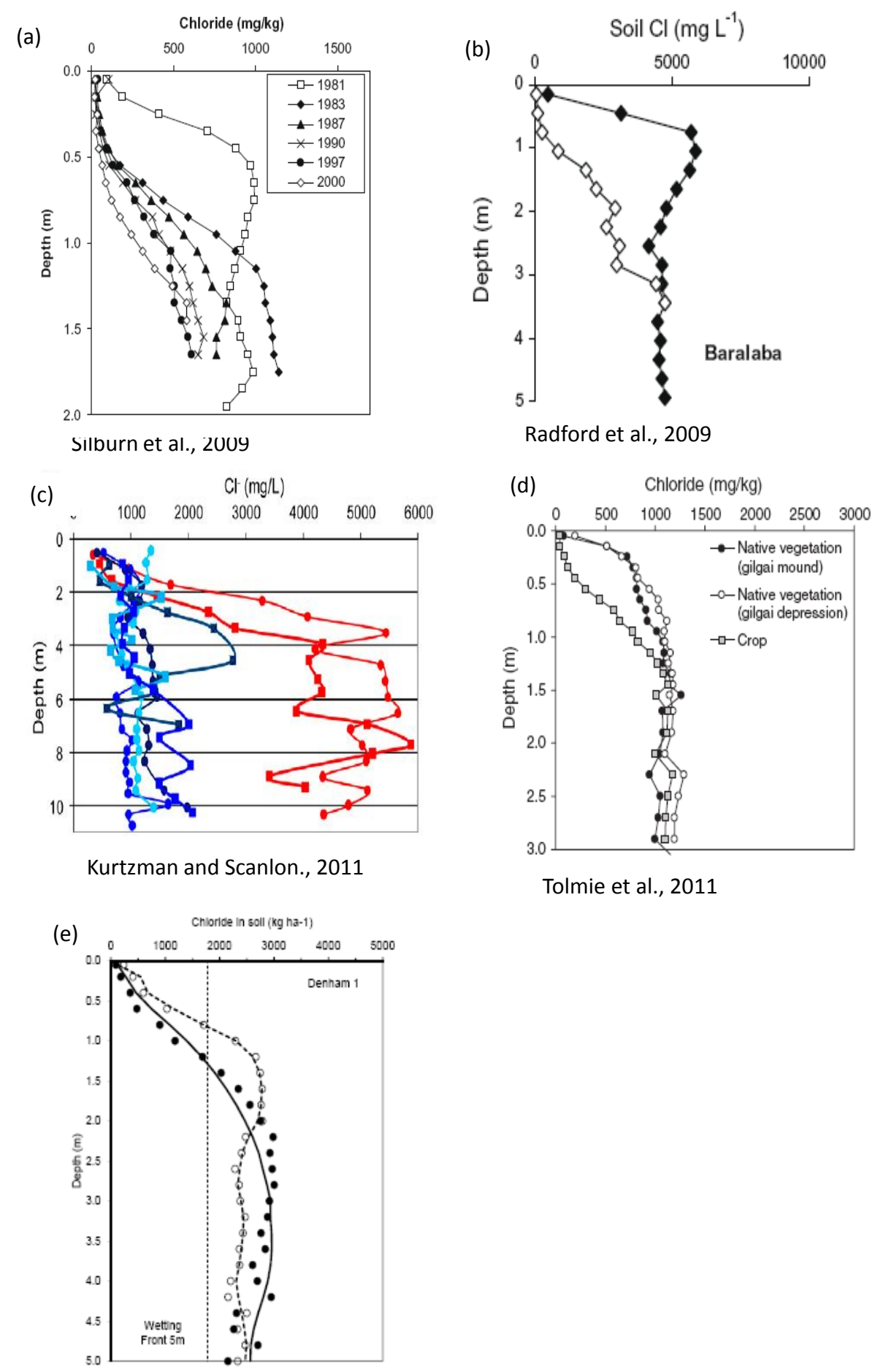

Timms et al., 2012

Figure 3. Flushing of chloride down through the unsaturated zone under cultivated vertisols: (a) Silburn et al. (2009) - 19 years of flushing; (b) Radford et al. (2009) - full diamond, native vegetation; empty, annual cropping; flushing from the top $3 \mathrm{~m}$ (c) Kurtzman and Scanlon (2011) - red, natural land; blue, irrigated cropping; flushing from 2-10 m depth; (d) Tolmie et al. (2011) - flushing from the top 1.5 m. (e) Timms et al. (2012) - black, cropping; empty - grass; flushing from the top $2 \mathrm{~m}$. 
use change. Timms et al. (2012) inferred, from combined soil and groundwater data, deep drainage and salt leaching after conversion to cropping under gray vertosols in the MurrayDarling Basin. Fresh groundwater was found in that study under shallower saline waters, strengthening the source of groundwater salinity from the vadose zone.

Scanlon et al. (2009) compared mobilization of solutes in the vadose zone after a change in the natural landscape to cultivated fields in three semiarid regions: Amargosa Desert (southwestern USA), southern High Plains (central USA) and Murray Basin (southeast Australia). Flushing of chloride from the top 6-10 $\mathrm{m}$ of the vadose zone after cultivation was very clear (e.g., Fig. 3 in Scanlon et al., 2009). Flushing has been observed in many arid and semiarid regions, and not exclusively related to vertisols (e.g., Oren et al., 2004, in the arid Arava Valley, southern Israel). Nevertheless, salinization of an aquifer due to cultivation and salt mobilization may be more pronounced under vertisols due to preferentialflow paths related to soil cracks (enabling the native aquifer to be relatively fresh) and the cracks evaporative capabilities (making the native deep vadose zone more saline).

A good example of an aquifer in which vertisols made a difference is the Mediterranean coastal aquifer in Israel (Fig. 4). Although known as a coastal aquifer, the phenomena discussed here are all a few kilometers inland and are not related to seawater intrusions. The parts of this aquifer overlain by vertisols were salinized a few decades after intensivecultivation, whereas the water in those parts of the aquifer overlain by cultivated loamy sand is still potable (Kurtzman, 2011; Kurtzman and Scanlon, 2011; Fig. 4). Similar to the Murray-Darling Basin (Timms et al., 2012), the upper groundwater under vertisols in this aquifer were more saline than the deep groundwater (e.g., Fig. 1 in Baram et al., 2014). Identification of the source of the salt and the cause of the salinization in the deep unsaturated zone under vertisols and land-use change, respectively, contradicted previous works, which attributed the salinization of these parts of the Israeli coastal aquifer to the intrusion of deep brines and intensive pumping (e.g., Vengosh and Ben-Zvi, 1994; Avisar et al., 2004). A different and shorter temporal trend that might also be interpreted in light of soils covering the recharge area is the response of groundwater salinity of the Israeli coastal aquifer to extreme precipitation (e.g., winter of 1991/1992): under vertisols, freshening of the aquifer (decrease in salinity) was generally observed due to recharge of freshwater through preferential paths, mostly under uncultivated parts; under loamy-sand soils, salinization of the aquifer was observed due to piston-flow recharge pushing relatively saline vadose-zone porewater down to the water table (Goldenberg et al., 1996; interpreted by Kurtzman and Scanlon, 2011).

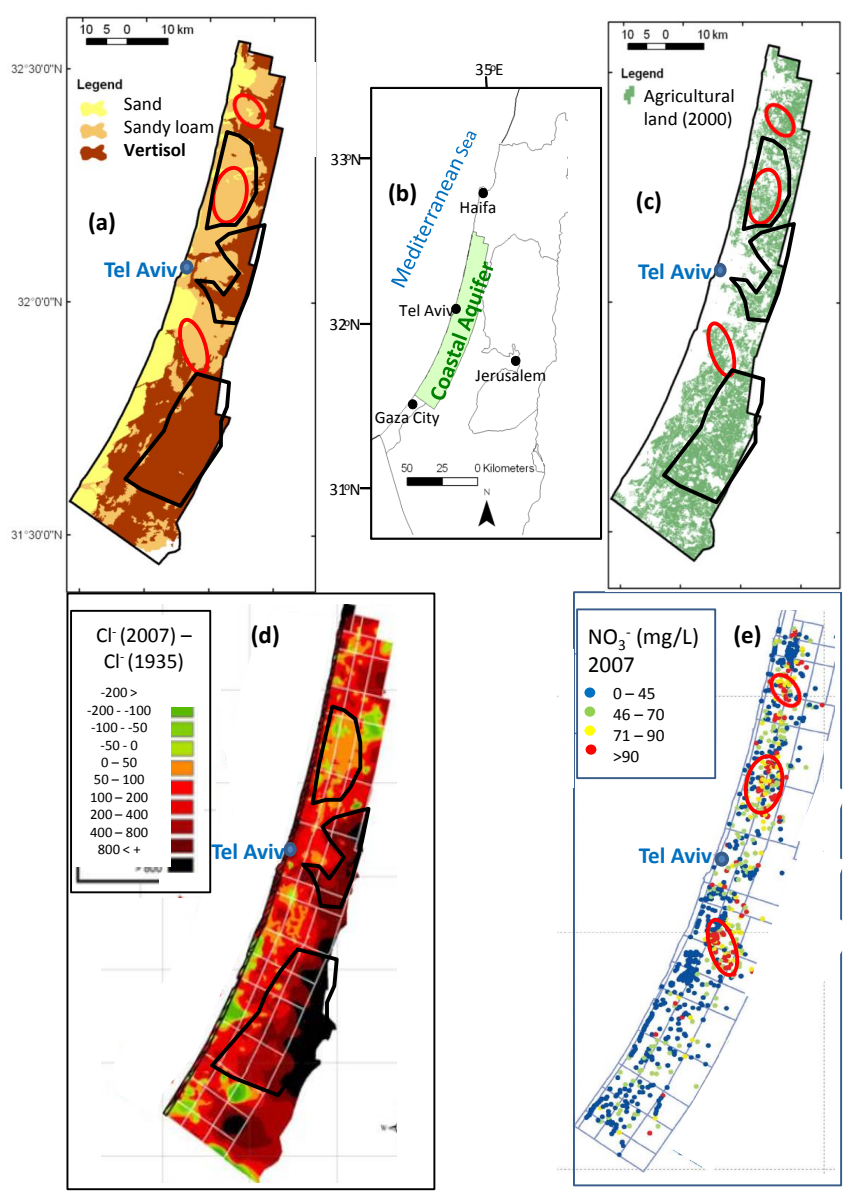

Figure 4. Plan views of the Israeli coastal aquifer. (a) Soil type (black polygons and red ellipses for spatial comparisons with panels $\mathrm{d}$ and e, respectively). (b) Location map. (c) Cultivated land in the year 2000. (d) Difference in chloride concentrations between 2007 and 1935 (modified from Livshitz and Zentner, 2009). Black polygons are characteristic cultivated areas that were severely salinized (southern polygons) and barely salinized (northern polygon) relative to soil type (panel a). (e) Nitrate concentration in groundwater wells in 2007 (modified from Hydrological Service, 2008). Red ellipses - areas with many wells contaminated with nitrate relative to soil type (panel a; modified from Kurtzman et al., 2013).

\section{Relatively little nitrate contamination in aquifers under vertisols}

Whereas the literature concerning salinization of aquifers and draining of salts from the vadose zone under cultivated vertisols is abundant, much less has been written about the contamination of groundwater by nitrate under these soils. Nitrate is the most problematic groundwater contaminant associated with agriculture worldwide (Jalali, 2005; Erisman et al., 2008; Burow et al., 2010; Vitousek et al., 2010; Kourakos et al., 2012). Both mineral nitrogen fertilizers (e.g., Kurtzman et al., 2013) and organic forms of nitrogen (e.g., Dahan et al., 2014) are often applied in excess with respect to 
the plants' ability to take up the nitrogen, leaving significant quantities of nitrate as a potential groundwater contaminant.

While in the previous sections aquifers under vertisols were shown to be vulnerable to salinization, due to the agricultural practice above, there is an increasing number of observations that indicate lesser nitrate contamination in groundwater under cultivated vertisols relative to groundwater of the same aquifer located under cultivated land of lighter soils. Kurtzman et al. (2013), dealing with nitrate contamination problems of the Israeli coastal aquifer, showed that at the groundwater basin scale $\left(\sim 2000 \mathrm{~km}^{2}\right)$ the contamination plumes of nitrate are present in the aquifer only under cultivated sandy loams, whereas under cultivated vertisols sporadic wells seldom produce water with nitrate concentration above the drinking-water standard (Fig. 4). Dafny (personal communication, 2014) revealed, by chi-square analysis, that groundwater under cultivated vertisols and a thick clayeyalluvial unsaturated zone is less likely than groundwater, under coarser sediments, to get contaminated by nitrate in the Condamine floodplain aquifer in Australia.

In contrast to the relatively high capability of vertisols to reduce nitrate leaching from cultivated land, both Baram et al. (2014; Israel, Coastal Aquifer) and Dafny (personal communication, 2014; Condamine floodplain, eastern Australia) acknowledge that CAFOs can be significant point sources of nitrate in vertisols as well. This might be due to incidental percolation of CAFO wastewater through the crack systems.

Silburn et al. (2013) indicated that modern deep drainage and solutes are still migrating down through the unsaturated zone in vertisol-alluvial systems in Australia and the nitrate is accumulating in the unsaturated zone. Nevertheless in vertisols areas overlaying the Israeli coastal aquifer, the rise in salinity and unsaturated-flow and transport models, indicate that the cultivation effects reached the water table, yet nitrate contamination is not severe, suggesting other mechanism are responsible for the low levels of nitrate contamination.

Denitrification in clayey soils is thought to be the major reason for the reduced deep leaching of nitrate in semiarid climates; this reduction of nitrate to gaseous nitrogen is less likely to be significant in lighter soils (Sigunga et al., 2002; Baram et al., 2012b; Boy-Roura et al., 2013; He et al., 2013).

Jahangir et al. (2012) found that adding carbon to deeper soil horizons significantly enhances denitrification in those layers. Profiles of dissolved organic carbon (DOC) in deep vadose zones (down to $9 \mathrm{~m}$ below ground) under citrus orchards on thick vertisols versus sandy-loam in Israel were compared. Whereas DOC in the lighter soils was higher than $15 \mathrm{mg} \mathrm{kg}_{\text {dry soil }}^{-1}$ only in the top $1 \mathrm{~m}$, in the vertisols it was above $30 \mathrm{mg} \mathrm{kg}_{\text {dry oil }}^{-1}$ in the entire $9 \mathrm{~m}$ profile (Shapira, 2012). These latter two studies support the notion that denitrification in the root zone, and perhaps beyond, results in less nitrate problems in aquifers under cultivated vertisols than under lighter soils. Thayalakumaran et al. (2014) reported high DOC in shallow groundwater overlain by irrigated sug- arcane corresponds with the absence of nitrate in this aquifer in northeast Australia.

Denitrification in the root zone and deeper in the soil profile explains the small amount of nitrate leached to the groundwater under rice fields in clayey soils in California, USA (Liang et al., 2014). Shallow groundwater $(<1.5 \mathrm{~m})$ under cultivated vertisols (e.g., the Netherlands) showed large variability (spatial and temporal) in nitrate concentration, probably due to the highly variable oxygen concentrations and therefore variability in nitrogen transformations in these systems (Hendriks et al., 1999).

A more speculative mechanism that might explain the relatively lower occurrence of groundwater nitrate contamination involves the anion-exchange capacity of the clay. Harmand et al. (2010) observed very significant adsorption of nitrate to kaolinite and oxyhydroxides under a fertilized coffee plantation growing on an acrisol in Costa Rica. In vertisols, montmorillonite is usually the dominant clay mineral; nevertheless, some kaolinite is found in most vertisols (e.g., Singh and Heffernan, 2002; Krull and Skjemstad, 2003; Baram et al., 2012b). Another drawback of this mechanism as dominant in vertisols is the adsorption of anions to a positively charged surface is more efficient at low $\mathrm{pH}$, while vertisols in semiarid regions are usually neutral to alkaline. Retardation of nitrate in the vadose zone due to adsorption to positively charged sites within the clay might slow down groundwater contamination under cultivated vertisols. Nevertheless, if significant, this mechanism would only retard groundwater contamination, whereas denitrification removes the nitrogen from the soil - unsaturated zone - aquifer system. The idea of nitrate adsorption has been tested as an engineered solution for reducing deep nitrate percolation. Artificially synthesized materials that have nitratesorption capacity (e.g., $\left[\mathrm{Mg}_{0.82}^{2+} \mathrm{Al}_{0.18}^{3+}(\mathrm{OH})_{2}\right]^{0.18+}\left[(\mathrm{Cl}-)_{0.18}\right.$ $\left.0.5(\mathrm{H} 2 \mathrm{O})]^{0.18-}\right)$ are being tested as soil additives to buffer nitrate leaching (Torres-Dorante et al., 2009).

\section{Conclusions}

Vertisols are considered arable soils in semiarid climates, and are intensively cultivated. Located in lowlands, vertisols often overlie aquifers. Flow and transport through the cracking clays is complex and results in unique land-aquifer phenomena. Observations from the lysimeter to basin scale have shown (directly and indirectly) the significance of cracks as preferential-flow paths in vertisols that bypass matrix blocks in the unsaturated zone. These preferential paths support recharge with relatively fresh water in uncultivated vertisols, and groundwater contamination from point sources such as CAFOs and under some conditions, from crop fields. Deep soil samples under uncultivated vertisols in semiarid regions reveal a dry (immobile), saline matrix, partly due to enhanced evaporation through the soil cracks. This evaporation is related to convective instability due to colder air at ground 
surface and warmer air deep in the crack during the night. In some aquifers lying beneath vertisols in these regions, relatively fresh groundwater exists under the saline unsaturated zone. Land-use change to cropland promotes greater fluxes through the saline matrix, which flush salts into the aquifer and eventually cause groundwater salinization. In contrast to the vulnerability of groundwater under vertisols to salinization, observations show that this soil-aquifer setting has some resistance to groundwater contamination by nitrate (the major agriculturally related groundwater contamination). Denitrification is probably the main mechanism supporting this resistance, whereas anion-exchange capacity may have a retarding effect as well.

Acknowledgements. The study was supported by the Agricultural Research Organization (ARO), Israel.

Edited by: M. Vanclooster

\section{References}

Acworth, R. I. and Timms, W. A.: Evidence for connected water processes through smectite-dominated clays at Breeza, New South Wales, Aust. J. Earth Sci., 56, 81-96, 2009.

Adams, J. E. and Hanks, R. J.: Evaporation from Soil Shrinkage Cracks, Soil Sci. Soc. Am. J., 28, 281-284, 1964.

Ahmad, N. and Mermut, A.: Vertisols and technologies for their management, Developments in Soil Science, Volume 24, Elsevier Science, Netherlands, 1996.

Allen, P. M., Harmel, R. D., Arnold, J., Plant, B., Yelderman, J., and King, K.: Field data and flow system response in clay (Vertisol) shale terrain, north central Texas, USA, Hydrol. Process., 19, 2719-2736, doi:10.1002/hyp.5782, 2005.

Allison, G. B. and Hughes, M. W.: The use of natural tracers as indicators of soil-water movement in a temperate semi-arid region, J. Hydrol., 60, 157-173, 1983.

Arnold, J. G., Potter, K. N., King, K . W., and Allen, P. M.: Estimation of soil cracking and the effect on the surface runoff in a Texas Blackland Prairie watershed, Hydrol. Process., 19, 589603, doi:10.1002/hyp.5609, 2005.

Arnon, S., Dahan, O., Elhanany, S., Cohen, K., Pankratov, I., Gross, A., Ronen, Z., Baram, S., and Shore, L.S .: Transport of testosterone and estrogen from dairy farm waste lagoons to groundwater, Environ. Sci. Technol., 42, 5521-5526, 2008.

Avisar, D., Rosenthal, E., Shulman, H., Zilberbrand, M., Flexer, A., Kronfeld, J., Ben Avraham, Z., and Fleischer, L.: The Pliocene Yafo Fm in Israel: hydrogeologically inert or active?, Hydrogeol. J., 12, 291-304, 2004.

Bandyopadhyay, K. K., Misra, A. K., Ghosh, P. K., Hati, K. M., Mandal, K. G., and Moahnty, M.: Effect of irrigation and nitrogen application methods on input use efficiency of wheat under limited water supply in a Vertisol of Central India, Irrig. Sci., 28, 285-299, 2010.

Baram, S., Arnon, S., Ronen, Z., Kurtzman, D., and Dahan, O.: Infiltration mechanism controls nitrification and denitrification processes under dairy waste lagoons, J. Environ. Qual., 41, 16231632, 2012a.
Baram, S., Kurtzman, D., and Dahan, O.: Water percolation through a clayey vadose zone, J. Hydrol., 424-425, 165-171, 2012b.

Baram, S., Ronen, Z., Kurtzman, D., Külls, C., and Dahan, O.: Desiccation-crack-induced salinization in deep clay sediment, Hydrol. Earth Syst. Sci., 17, 1533-1545, doi:10.5194/hess-171533-2013, 2013.

Baram, S., Kurtzman, D., Ronen, Z., Peeters, A., and Dahan, O.: Assessing the impact of dairy waste lagoons on groundwater quality using a spatial analysis of vadose zone and groundwater information in a coastal phreatic aquifer, J. Environ. Manage., 132, 135-144, 2014.

Ben-Hur, M. and Assouline S.: Tillage effects on water and salt distribution in a vertisol during effluent irrigation and rainfall, Agron. J., 94, 1295-1304, 2002.

Beven, K. and Germann, P.: Macropores and water flow in soils revisited, Water Resour. Res., 49, 3071-3092, doi:10.1002/wrcr.20156, 2013.

Bhattacharyya, T., Pal, D. K., and Deshpande, S. B.: Genesis and transformation of minerals in the formation of red (alfisols) and black (inceptisols and vertisols) soils on Deccan Basalt in the Western Ghats, India, J. Soil Sci., 44, 159-171, 1993.

Boy-Roura, M., Nolan, B. T., Menció, A., and Mas-Pla, J.: Regression model for aquifer vulnerability assessment of nitrate pollution in the Osona region (NE Spain), J. Hydrol., 505, 150-162, 2013.

Brady, N. C. and Weil, R. R.: The Nature and Properties of Soils, thirteenth ed., Pearson Education, New Jersey, 2002.

Bronswijk, J. J. B.: Modeling of water balance, cracking and subsidence of clay soils, J. Hydrol., 97, 199-212, 1988.

Bronswijk, J. J. B.: Relation between vertical soil movements and water-content changes in cracking clays, Soil Sci. Soc. Am. J., 55, 1220-1226, 1991.

Bronswijk, J. J. B., Hamminga, W., and Oostindie, K.: Field-scale solute transport in a heavy clay soil, Water Resour. Res., 31, 517526, 1995.

Burow, K. R., Nolan, B. T., Rupert, M. G., and Dubrovsky, N. M.: Nitrate in groundwater of the United States, 1991-2003, Environ. Sci. Technol., 44, 4988-4997, doi:10.1021/es100546y, 2010

Chan, K. Y. and Hodgson, A. S.: Moisture regimes of a cracking clay soil under furrow irrigated cotton, Aust. J. Exp. Agr., 21, 538-542, 1981.

Chen, C. C., Roseberg, R. J., and Selker, J. S.: Using microsprinkler irrigation to reduce leaching in a shrink/swell clay soil, Agric. Water Manage., 54, 159-171, 2002.

Chertkov, V. Y.: The shrinkage geometry factor of a soil layer, Soil Sci. Soc. Am. J., 69, 1671-1683, doi:10.2136/sssaj2004.0343, 2005.

Chertkov, V. Y., Ravina, I., and Zadoenko, V.: An approach for estimating the shrinkage geometry factor at a moisture content, Soil Sci. Soc. Am. J., 68, 1807-1817, 2004.

Coppola, A., Gerke, H. H., Comegna, A., Basile, A., and Comegna, V.: Dual-permeability model for flow in shrinking soil with dominant horizontal deformation, Water Resour. Res., 48, W08527, doi:10.1029/2011WR011376, 2012.

Dafny E. and Silburn D. M.: The hydrogeology of the Condamine River Alluvial Aquifer, Australia: a critical assessment, Hydrogeol. J., 22, 705-727, 2014.

Dahan, O., Talby, R., Yechieli, Y., Adar, E., Lazarovitch, N., and Enzel, Y.: In situ monitoring of water percolation and solute trans- 
port using a vadose zone monitoring system, Vadose Zone J., 8, 916-925, doi:10.2136/vzj2008.0134, 2009.

Dahan, O., Babad, A., Lazarovitch, N., Russak, E. E., and Kurtzman, D.: Nitrate leaching from intensive organic farms to groundwater, Hydrol. Earth Syst. Sci., 18, 333-341, doi:10.5194/hess-18-333-2014, 2014.

Dalton, P., Raine, S. R., and Broadfoot, K.: Best management practices for maximising whole farm irrigation efficiency in the Australian cotton industry, Final report to the Cotton Research and Development Corporation, National Centre for Engineering in Agriculture Report, 179707/2, USQ, Toowoomba, 2001.

Erisman, J. W., Sutton, M. A., Galloway, J. N., Klimont, Z., and Winiwarter, W.: How a century of ammonia synthesis changed the world, Nat. Geosci., 1, 636-639, 2008.

FAO Corporate Document Repository: Lecture notes on the major soils of the world, available at: http://www.fao.org/docrep/003/ y1899e/y1899e06.htm, last access: July 2015.

Gerke, H. H.: Preferential flow descriptions for structured soils, J. Plant Nutr. Soil Sci., 169, 382-400, doi:10.1002/jpln.200521955, 2006.

Gerke, H. H. and van Genuchten, M. Th.: A dual-porosity model for simulating the preferential movement of water and solutes in structured porous media, Water Resour. Res., 29, 305-319, 1993.

Germann, P. F. and Beven, K.: Kinematic wave approximation to infiltration into soils with sorbing macropores, Water Resour. Res., 21, 990-996, 1985.

Goldenberg, L. C., Melloul, A. J., and Zoller, U.: The "short cut" approach for the reality of enhanced groundwater contamination, J. Environ. Manage., 46, 311-326, doi:10.1006/jema.1996.0024, 1996.

Graham, R. C., Ulery, A. L., Neal, R. H., and Teso, R .R.: Herbicide residue distributions in relation to soil morphology in two California vertisols, Soil Sci., 153, 115-121, 1992.

Greve, A., Andersen, M. S., and Acworth, R. I.: Investigations of soil cracking and preferential flow in a weighing lysimeter filled with cracking clay soil, J. Hydrol., 393, 105-113, 2010.

Gunawardena, T. A., McGarry, D., Robinson, J. B., and Silburn, D. M.: Deep drainage through Vertosols in irrigated fields measured with drainage lysimeters, Soil Res., 49, 343-354, 2011.

Hardie, M. A., Cotching, W. E., Doyle, R. B., Holz, G., Lisson, S., and Mattern, K.: Effect of antecedent soil moisture on preferential flow in a texture-contrast soil, J. Hydrol., 398, 191-201, 2011.

Harmand, J. M., Avila, H., Oliver, R., Saint-Andre, L., and Dambrine, E.: The impact of kaolinite and oxi-hydroxides on nitrate adsorption in deep layers of a Costarican Acrisol under coffee cultivation, Geoderma, 158, 216-224, 2010.

Harris, G. L., Nicholls, P. H., Bailey, S. W., Howse, K. R., and Mason, D. J.: Factors influencing the loss of pesticides in drainage from a cracking clay soil, J. Hydrol., 159, 235-253, 1994.

Hati, K. M., Swarup, A., Dwivedi, A. K., Misra, A. K., and Bandyopadhyay, K. K.: Changes in soil physical properties and organic carbon status at the topsoil horizon of a vertisol of central India after 28 years of continuous cropping, fertilization and manuring, Agric. Ecosyst. Environ., 119, 127-134, 2007.

He, J., Dougherty, M., and AbdelGadir, A.: Numerical assisted assessment of vadose-zone nitrogen transport under a soil moisture controlled wastewater SDI dispersal system in a Vertisol, Ecol. Eng., 53, 228-234, 2013.
Hendriks, R. F .A., Oostindie, K., and Hamminga, P.: Simulation of bromide tracer and nitrogen transport in a cracked clay soil with the FLOCR/ANIMO model combination, J. Hydrol., 215, 94-115, 1999.

Hoogmoed, W. B. and Bouma, J.: A simulation model for predicting infiltration into cracked clay soil, Soil Sci. Soc. Am. J., 44, 458461, doi:10.2136/sssaj1980.03615995004400030003x, 1980.

Hua, K., Wang, D., Guo, X., and Guo, Z.: Carbon Sequestration Efficiency of Organic Amendments in a Long-Term Experiment on a Vertisol in Huang-Huai-Hai Plain, China, PLoS ONE, 9, e108594, doi:10.1371/journal.pone.0108594, 2014.

Hydrological Service: Current condition and development of water resources in Israel until autumn 2007, Annual report, Israel Water Authority, Jerusalem, 2008 (in Hebrew).

IUSS Working Group WRB: World Reference Base for Soil Resources, 2014, International soil classification system for naming soils and creating legends for soil maps, World Soil Resources Reports No. 106, FAO, Rome, 2014.

Jahangir, M. M. R., Khalil, M. I., Johnston, P., Cardenas, L. M., Hatch, D. J., Butler, M., Barrett, M., O'flaherty, V., and Richards, K. G.: Denitrification potential in subsoils: a mechanism to reduce nitrate leaching to groundwater, Agric. Ecosyst. Environ., 147, 13-23, 2012.

Jalali, M.: Nitrates leaching from agricultural land in Hamadan, western Iran, Agric. Ecosyst. Environ., 110, 210-218, 2005.

Jarvis, N. J., Stähli, M., Bergström, L., and Johnsson, H.: Simulation of dichlorprop and bentazon leaching in soils of contrasting texture using the MACRO model, J. Environ. Sci. Health, A29, 1255-1277, 1994.

Jolly, I. D., Cook, P. G., Allison, G. B., and Hughes, M. W.: Simultaneous water and solute movement through unsaturated soil following an increase in recharge, J. Hydrol., 111, 391-396, doi:10.1016/0022-1694(89)90270-9, 1989.

Kamai, T., Weisbrod, N., and Dragila, M. I.: Impact of ambient temperature on evaporation from surface-exposed fractures, Water Resour. Res., 45, W02417, doi:10.1029/2008WR007354, 2009.

Kelly, B. P. and Pomes, M. L.: Preferential flow and transport of nitrate and bromide in claypan soil, Ground Water, 36, 484-494, doi:10.1111/j.1745-6584.1998.tb02820.x, 1998.

Köhne, J. M., Köhne, S., and Simunek, J.: A review of model applications for structured soils: a) water flow and tracer transport, J. Contam. Hydrol., 104, 4-35, 2009.

Kosmas, C., Moustakas, N., Kallianou, C., and Yassoglou, N.: Cracking patterns, bypass flow and nitrate leaching in Greek irrigated soils, Geoderma, 49, 139-152, 1991.

Kourakos, G., Klein, F., Cortis, A., and Harter, T.: A groundwater nonpoint source pollution modeling framework to evaluate longterm dynamics of pollutant exceedance probabilities in wells and other discharge locations, Water Resour. Res., 48, W00L13, doi:10.1029/2011WR010813, 2012.

Krull, E. S. and Skjemstad, J.O.: Delta(13)C and delta(15)N profiles in (14)C-dated Oxisol and Vertisols as a function of soil chemistry a mineralogy, Geoderma, 112, 1-29, 2003.

Kurtzman, D.: The soil, the unsaturated zone, and groundwatersalinization in the south-eastern part of the (Israeli) Coastal Aquifer Agricultural Research Organization publication no. 603/11 (in Hebrew), available upon request: daniel@volcani.agri.gov.i1, 2011. 
Kurtzman, D. and Scanlon, B. R.: Groundwater recharge through vertisols: irrigated cropland vs. natural land, Israel, Vadose Zone J., 10, 662-674, 2011.

Kurtzman, D., Shapira, R. H., Bar-Tal, A., Fine, P., and Russo, D.: Nitrate fluxes to groundwater under citrus orchards in a Mediterranean climate: observations, calibrated models, simulations and agro-hydrological conclusions, J. Contam. Hydrol., 151, 93-104, 2013.

Larsbo, M., Roulier, S., Stenemo, F., Kastreel, R., and Jarvis, N.: An improved dual-permeability model of water flow and solute transport in the vadose zone, Vadose Zone J., 4, 398-406, 2005.

Liang, X. Q., Harter, T., Porta, L., van Kessel, C., and Linquist, B. A.: Nitrate leaching in Californian rice fields: a field and regional-scale assessment, J. Environ. Qual., 43, 881-894, 2014.

Lin, H. and McInnes, K.: Water-flow in clay soil beneath a tension infiltrometer, Soil Sci. 159, 375-382, 1995.

Liu, C. W., Chen, S. K., and Jang, C. S.: Modelling water infiltration in cracked paddy field soil, Hydrol. Process., 18, 2503-2513, doi:10.1002/hyp.1478, 2004.

Liu, Y. Y., Evans, J. P., McCabe, M. F., de Jeu, R. A. M., van Dijk, A. I. J. M., and Su, H.: Influence of cracking clays on satellite estimated and model simulated soil moisture, Hydrol. Earth Syst. Sci., 14, 979-990, doi:10.5194/hess-14-979-2010, 2010.

Livshitz, Y. and Zentner, E.: Changes in water and salt storage of the Coastal Aquifer during the years 1933-2007: development and application of a method and comparison to previous methods, A Hydrological Service Report, Israel Water Authority, 2009 (in Hebrew).

Moss, J., Gordon, I. J., and Zischke, R.: Best management practices to minimise below root zone impacts of irrigated cotton, Final report to the Murray-Darling Basin Commission (Project I6064), Department of Natural Resources and Mines, Queensland, 2001.

Nachshon, U., Weisbrod, N., and Dragila, M. I.: Quantifying air convection through surface-exposed fractures: a laboratory study, Vadose Zone J., 7, 948-956, 2008.

Novák, V., Šimůnek, J., and van Genuchten, M. Th. Infiltration of water into soils with cracks, ASCE J. Irrig. Drain. Eng., 126, 4147, 2000.

O'Leary, G. J.: The effects of conservation tillage on potential groundwater recharge, Agric. Water Manage., 31, 65-73, 1996.

Oren, O., Yechieli, Y., Bohlke, J. K., and Dody, A.: Contamination of groundwater under cultivated fields in an arid environment central Arava Valley, Israel, J. Hydrol., 290, 312-328, 2004.

Pathak, P., Sudi, R., Wani, S. P., and Sahrawat, K. L.: Hydrological behavior of Alfisols and Vertisols in the semi-arid zone: implications for soil and water management, Agric. Water Manage., 118, 12-21, 2013.

Radford, B. J., Silburn, D. M., and Forster, B. A.: Soil chloride and deep drainage responses to land clearing for cropping at seven sites in central Queensland, northern Australia, J. Hydrol., 379, 20-29. doi:10.1016/j.jhydrol.2009.09.040, 2009.

Raine, S. R. and Bakker, D.: Increased furrow irrigation efficiency through better design and management of cane fields, in: Proceedings of the Australian Society Sugar Cane Technologists, 119-124, 1996.

Rhoades, J. D., Lesch, S. M., Burch, S. L., Letey, J., LeMert, R. D. Shouse, P. J., Oster, J. D., and O'Halloran T.: Salt distributions in cracking soils and salt pickup by runoff waters, J. Irrig. Drain. Eng., 123, 323-328, 1997.
Richards, L. A.: Capillary conduction of liquids through porous mediums, Physics, 1, 318-333, 1931.

Ringrose-Voase, A. J. and Nadelko, A. J.: Deep drainage in a Grey Vertosol under furrow-irrigated cotton, Crop Pasture Sci., 64, 1155-1170, 2013.

Scanlon, B. R., Stonestrom, D. A., Reedy, R. C., Leaney, F. W., Gates, J., and Cresswell, R. G.: Inventories and mobilization of unsaturated zone sulfate, fluoride, and chloride related to land use change in semiarid regions, southwestern United States and Australia, Water Resour. Res., 45, W00A18, doi:10.1029/2008WR006963, 2009.

Selim, H. W. and Kirkham, D.: Soil temperature and water content changes during drying as influenced by cracks: a laboratory experiment, Soil Sci. Soc. Am. J., 34, 565-569, 1970.

Shapira, R. H.: Nitrate flux to groundwater under citrus orchards: observations, modeling and simulating different nitrogen application rates, M.Sc. Thesis, The Hebrew University of Jerusalem, 2012 (in Hebrew with English abstract).

Sigunga, D. O., Janssen, B. H., and Oenema, O.: Denitrification risks in relation to fertilizer nitrogen losses from Vertisols and Phaoezems, Commun. Soil Sci. Plant Anal., 33, 561-578, 2002.

Silburn D. M. and Montgomery J.: Deep drainage under irrigated cotton in Australia - A review, WATERpak a guide for irrigation management in cotton, Cotton Research and Development Corporation/Australian Cotton Cooperative Research Centre, Narrabri, 29-40, 2004.

Silburn, D. M., Cowie, B. A., and Thornton, C. M.: The Brigalow Catchment Study revisited: effects of land development on deep drainage determined from non-steady chloride profiles, J. Hydrol., 373, 487-498, doi:10.1016/j.jhydrol.2009.05.012, 2009.

Silburn, D. M., Tolmie, P. E., Biggs, A. J. W., Whish, J. P. M., and French, V.: Deep drainage rates of Grey Vertosols depend on land use in semi-arid subtropical regions of Queensland, Soil Res., 49, 424-438, doi:10.1071/SR10216, 2011.

Silburn, D. M., Foley, J. L., Biggs, A. J. W., Montgomery, A. J., and Gunawardena, T. A.: The Australian Cotton Industry and four decades of deep drainage research: a review, Crop Pasture Sci., 64, 1049-1075, 2013.

Šimůnek, J. and van Genuchten, M. T.: Modeling nonequilibrium flow and transport processes using HYDRUS, Vadose Zone J., 7, 782-797, 2008.

Šimůnek, J., Jarvis, N. J., van Genuchten, M. T., and Gärdenäs, A.: Review and comparison of models for describing nonequilibrium and preferential flow and transport in the vadose zone, J. Hydrol. 272, 14-35, doi:10.1016/S0022-1694(02)00252-4, 2003.

Šimůnek, J., Šejna, M., and van Genuchten M. T.: The DualPerm Module for HYDRUS (2-D/3-D) Simulating Two-Dimensional Water Movement and Solute Transport in Dual-Permeability Porous Media, Version 1.0, PC Progress, Prague, Czech Republic, 2012.

Singh, B. and Heffernan, S.: Layer charge characteristics of smectites from vertosols (vertisols) of New South Wales, Aust. J. Soil Res., 40, 1159-1170, doi:10.1071/SR02017, 2002.

Smith, R., Raine, S., and Minkevich, J.: Irrigation application efficiency and deep drainage potential under surface irrigated cotton, Agric. Water Manage., 71, 117-130, 2005.

Sun, H. and Cornish, P. S.: Estimating shallow groundwater recharge in the headwaters of the Liverpool Plains using SWAT, Hydrol. Process., 19, 795-807, 2005. 
te Brake, B., van der Ploeg, M. J., and de Rooij, G. H.: Water storage change estimation from in situ shrinkage measurements of clay soils, Hydrol. Earth Syst. Sci., 17, 1933-1949, doi:10.5194/hess17-1933-2013, 2013.

Tediosi, A., Whelan, M. J., Rushton, K. R., and Gandolfi, C.: Predicting rapid herbicide leaching to surface waters from an artificially drained headwater catchment using a one dimensional two-domain model coupled with a simple groundwater model, J. Contam. Hydrol., 145, 67-81, 2013.

Thayalakumaran T., Lenahan M. J., and Bristow K. L.: Dissolved organic carbon in groundwater overlain by irrigated sugarcane, Groundwater, 53, 525-530, 2014.

Timms, W. A., Young, R. R., and Huth, N.: Implications of deep drainage through saline clay for groundwater recharge and sustainable cropping in a semi-arid catchment, Australia, Hydrol. Earth Syst. Sci., 16, 1203-1219, doi:10.5194/hess-16-12032012, 2012.

Tolmie, P. E., Silburn, D. M., and Biggs, A. J. W.: Deep drainage and soil salt loads in the Queensland Murray-Darling Basin using soil chloride: comparison of land uses, Soil Res., 49, 408423, 2011.

Torres-Dorante, L. O., Lammel, J., and Kuhlmann, H.: Use of a layered double hydroxide (LDH) to buffer nitrate in soil: longterm nitrate exchange properties under cropping and fallow conditions, Plant Soil, 315, 257-272, 2009.

Van Dam, J. C.: Simulation of field-scale water flow and bromide transport in a cracked clay soil, Hydrol. Process., 14, 1101-1117, 2000.

Van Dam, J. C., Groenendijk, P., Hendriks, R. F. A., and Kroes, J. G.: Advances of modeling water flow in variably saturated soils with SWAP, Vadose Zone J., 7, 640-665, 2008.
Vengosh, A. and Ben-Zvi, A.: Formation of a salt plume in the Coastal Plain aquifer of Israel: the Be'er Toviyya region, J. Hydrol., 160, 21-52, doi:10.1016/0022-1694(94)90032-9, 1994.

Vitousek, P. M., Naylor, R., Crews, T., David, M. B., Drinkwater, L. E., Holland, E., Johnes, P. J., Katzenberger, J., Martinelli, L. A., Matson, P. A., Nziguheba, G., Ojima, D., Palm, C. A., Robertson, G. P., Sanchez, P. A., Townsend, A. R., and Zhang, F. S.: Nutrient imbalances in agricultural development, Science, 324, 1519-1520. doi:10.1126/science.1170261, 2010.

Weaver, T. B., Ghadiri, H., Hulugalle, N. R., and Harden, S.: Organochlorine pesticides in soil under irrigated cotton farming systems in Vertisols of the Namoi Valley, north-western New South Wales, Australia, Chemosphere, 88, 336-343, 2012.

Weaver, T. B., Hulugalle, N. R., Ghadiri, H., and Harden, S.: Quality of drainage water under irrigated cotton in Vertisol of the lower Namoi Valley, New South Wales, Australia, Irrig. Drainage, 62, 107-114, doi:10.1002/ird.1706, 2013.

Weisbrod, N. and Dragila, M. I.: Potential impact of convective fracture venting on salt-crust buildup and ground-water salinization in arid environments, J. Arid Environ., 65, 386-399, 2006.

Weisbrod, N., Dragila, M. I., Nachshon, U., and Pillersdorf, M.: Falling through the cracks: the role of fractures in Earthatmosphere gas exchange, Geophys. Res. Lett., 36, L02401, doi:10.1029/2008GL036096, 2009.

Yaalon, D. H.: Soils in the Mediterranean region: what makes them different?, Catena, 28, 157-169, 1997.

Young, R., Huth, N., Harden, S., and McLeod, R.: Impact of rainfed cropping on the hydrology and fertility of alluvial clays in the more arid areas of the upper Darling Basin, eastern Australia, Soil Res., 52, 388-408, 2014. 